УДК

\title{
ИССЛЕДОВАНИЕ ЛИНЕЙНОСТИ ИНТЕРМОДУЛЯЦИОННОЙ ХАРАКТЕРИСТИКИ МШУ ПРИ ОПТИМАЛЬНОМ СМЕЩЕНИИ ДЛЯ БЕСПРОВОДНОЙ ЛОКАЛЬНОЙ СЕТИ
}

СИНГХ И. В., АЛАМ М. С.

Алигархский мусульманский университет, Индия, Алигарх, Уттар-Прадеш

\begin{abstract}
Аннотация. В работе представлено исследование влияния эффекта изменения технологических параметров новых полевых МОП-транзисторов со структурой SOI (Silicon-on-Insulator) и частичным перекрытием затвора MOSFET (metal-oxide-semiconductor field-effect transistor) на линейность каскодного малошумящего усилителя (МШУ), применяющегося в беспроводных локальных сетях (WLAN). С помощью количественной оценки линейности МШУ посредством точки пересечения третьего порядка (IP3) в работе даны рекомендации по определению оптимального размера спейсера (spacer) $s$, толщины пленки $T_{\mathrm{Si}}$, градиента легирующей примеси $d$ и длины затвора $L_{\mathrm{G}}$ полевого транзистора с частичным перекрытием затвора для повышения линейности МШУ. На основе нового показателя качества МШУ (FoM $\left.\mathrm{LNA}_{\mathrm{LA}}\right)$, включающего коэффициент усиления сигнала по мощности $G$, показатель IP3, коэффициент шума NF и потребляемую

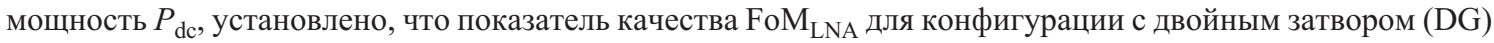
намного выше, чем для конфигурации с одиночным затвором (SG) при оптимальном напряжении смещения затвора $V_{\mathrm{OD}}=75 \mathrm{MB}$. Это обусловлено комбинированным эффектом повышения коэффициента усиления $G$ и показателя IP3 в конфигурации с двойным затвором. При сравнении с доступными экспериментальными данными для 0,18 мкм балк-технологии установлено, что при использовании новых полевых МОП-транзисторов со структурой SOI и частичным перекрытием затвора с длиной затвора $L_{\mathrm{G}}=60$ нм (эффективная длина затвора $L_{\mathrm{eff}}=92 \mathrm{нм)} \mathrm{оптимально} \mathrm{спроектированный} \mathrm{МШУ} \mathrm{с} \mathrm{оптимальным} \mathrm{смещением}$ обеспечивает двукратное повышение предлагаемого показателя качества FoM $\mathrm{LNA}_{\text {. }}$. При оптимальном смещении МШУ получены следующие показатели: коэффициент шума NF $~ 2,27$ дБ, IP3 +7,75 дБм, $G \sim$ 20,86 дБ, потребляемая мощность 2,5 мВт.
\end{abstract}

Ключевые слова: нелинейная схема; двойной затвор; SOI; кремний-на-диэлектрике; малошумящий усилитель; МШУ; малая мощность

\section{1. ВСТУПЛЕНИЕ}

В настоящее время рынок беспроводных телефонов является одним из крупнейших глобальных рынков для радиочастотной полупроводниковой промышленности [1]. Портативные беспроводные вычислительные устройства обеспечили повышенный спрос на локальные сети (LAN) [1]. Одними из последних новинок среди подобных сетей являются беспроводные LAN на основе мультиплексирования с ортогональным частотным разделением (OFDM), которые обеспечивают высокие скорости передачи данных в ISM-диапазоне 5-6 ГГц [2].

В этой полосе частот для разработки входных блоков малошумящих усилителей (МШУ) предложены различные решения, проведено проектирование и изготовление различных блоков с использованием биполярных технологий, таких как GaAs HBT (Лотт, 1996), поле- 